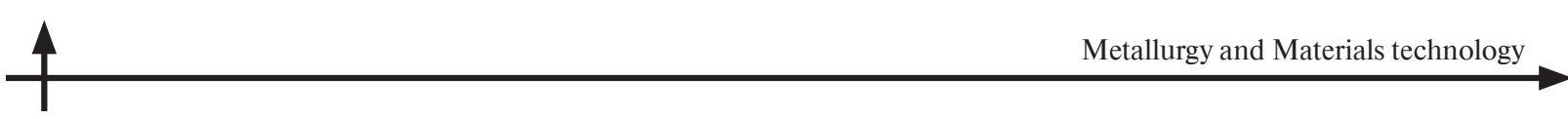

DOI 10.5862/JEST.249.9

УДК 54.057; 66.08, 669

A. Tonitzki, A.N. Skvortsova, T.S. Koltsova,

S.V. Ganin, M.A. Danilova, A.I. Shamshurin

\title{
ALUMINUM - CARBON NANOFIBERS COMPOSITE COATING PRODUCED BY COLD SPRAYING
}

\author{
А. Тониитзки, А.Н. Скбориова, Т.С. Кольиова, \\ С.В. Ганин, М.А. Данилова, А.И. Шамиурин
}

\section{ХОЛОДНОЕ ГАЗОДИНАМИЧЕСКОЕ НАПЫЛЕНИЕ ПОКРЫТИЙ СИСТЕМЫ АЛЮМИНИЙ - УГЛЕРОДНЫЕ НАНОВОЛОКНА}

\begin{abstract}
Carbon nanofiber (CNF) / aluminum hybrid material was prepared by direct synthesis of CNFs on the surface of aluminum powder particles in a fluidized bed reactor using acetylene and hydrogen at the temperature of $550^{\circ} \mathrm{C}$. This allowed to achieve a good dispersion of CNFs in an aluminum matrix with the CNF content up to $2 \%$. The possibility for producing coatings based on aluminum, reinforced by carbon nanostructures in cold gas-dynamic spraying was shown. The Al-CNFs coatings showed about a $60 \%$ increase in the hardness compared with pure Al coatings.
\end{abstract}

ALUMINU; SYNTHESIS; CARBON NANOFIBERS; COATING; POWDER METALLURGY.

\begin{abstract}
В статье представлены результаты работ по получению гибридного материала системы «углеродные нановолокна (УНВ) / алюминий» газофазным методом в реакторе кипящего слоя. Хорошая дисперсия углеродных структур была достигнута путем синтеза нановолокон из газовой фазы, с использованием ацетилен - водородной атмосферы при температуре $550{ }^{\circ} \mathrm{C}$, непосредственно на поверхности матричных металлических частиц в присутствии никелевого катализатора. Показана возможность получения покрытий на основе алюминия, армированного углеродными нановолокнами методом холодного газодинамического напыления при использовании гибридного порошкового материала с содержанием углерода до 2 масс. \%. Полученные покрытия при содержании 1 и 2 масс. \% углеродных нановолокон показали увеличение твердости на $60 \%$ по сравнению с покрытием из чистого алюминия.
\end{abstract}

\section{АЛЮМИНИЙ; СИНТЕЗ; УГЛЕРОДНЫЕ НАНОВОЛОКНА; ПОКРЫТИЯ; ПОРОШКОВАЯ МЕТАЛЛУРГИЯ.}

\section{Introduction}

Recently, metal matrix composite materials reinforced with carbon nanotubes (CNT) and carbon nanofibers (CNF), is the object of study of a large number of researchers [1]. This is due to the unique properties of CNTs, such as the strength of up to $63 \mathrm{GPa}$ [2] and the thermal conductivity of $3000 \mathrm{~W} / \mathrm{mK}$ [3]. Uniform distribution of carbon nanotubes in the metal matrix remains a challenge due to their high propensity for agglomeration. The authors try to solve the problem in the stage of preparation of the composite powder and in stage of compaction [1].

Most traditional methods of mixing powders of the matrix and the CNTs is a mechanical grinding in a ball mill [4-6], ultrasonic mixing [7] and spray drying of small metal particles with CNTs [8]. To create a compact materials based on metals, reinforced by CNTs, technology of powder metallurgy $[9,10]$, galvanic plating [11], sintering in spark plasma [12, 13], mechanical alloying [14] and thermal spraying are used [15, 16].

Thermal spraying is a very promising method for the production of metal-CNT based composites. It can be used for the production of coatings with high wear resistance. The method has the great advantage over conventional powder metallurgy, since it allows to obtain uniform distribution of the carbon nanotubes in complex shaped structures and coatings. 
However, the high speed impact along with high temperatures may lead to the destruction of carbon nanostructures [17].

Cold gas dynamic spraying or just cold spraying (CS) is a process in which solid powders are accelerated in a Laval nozzle toward to a substrate at a temperature significantly below the melting point [18]. When unmelted metal particles bumps on a substrate of plastic deformation occurs and the kinetic energy of the particles is converted to heat and, in part, to binding energy with the substrate, providing the formation of a continuous layer of densely packed metal particles. CS is a high deposition rate coating process that utilizes kinetic rather than thermal energy. The cold spray process has several advantages, as there is no oxidation and phase transformation involved due to the low temperature of the process.

In [8] it was possibility to obtain coatings based on aluminum reinforced by multilayer carbon nanotubes using cold gas dynamic spraying, up to a thickness of 500 microns. To obtain a good distribution of carbon nanostructures in the matrix, the authors used spray drying of Al-Si eutectic powder with pure CNTs. The dry powder contained $5 \mathrm{wt} \%$ of CNT and were mixed with pure aluminum in a ball mill. After ball milling the $\mathrm{Al}-\mathrm{Si}$ particles agglomerated with the CNTs to a size of $\sim 50$ microns. The final content of the carbon nanostructures in the powder was $0,5-1 \mathrm{wt} . \%$. The authors obtained a good distribution of carbon nanostructures in the coating.

The presented article devoted to obtain a composite powder material based on aluminum, in which a good dispersion of carbon nanostructures achieved by synthesis of nanofibers from the gas phase of the metal matrix particles directly on the surface by addition of the nickel based catalyst. The possibility of using this composite powder for the production of coatings by cold gas-dynamic spraying was examined.

\section{Experiment details}

As the starting material aluminum powder (brand PA-4) with a purity of $99,5 \mathrm{wt} . \%$ was used. The main impurities are silicon, iron and copper with a content of not more than 0,$4 ; 0,35$ and $0,02 \mathrm{wt} . \%$, respectively.

The composite particulate material was synthesized by a chemical vapor deposition (CVD) in a fluidized bed reactor as shown in the aig.1. This method is considered as the most viable and efficient process for high-yield production of carbon nanotubes. For the synthesis a fluidized bed reactor (fig. 1,a) which consists of a quartz tube inserted into a vertical furnace (hot zone $60 \mathrm{~cm}$ ). The quartz tube was conically shaped with a junction from internal diameters of 6 to $34 \mathrm{~mm}$ with a cone zone length of $20 \mathrm{~cm}$.

Gas-dynamic spraying was conducted on a 405 DYMET installation in an air jet at a pressure of $7 \mathrm{~kg} / \mathrm{cm}^{2}$ and $600 \mathrm{~m} / \mathrm{s}$ speed, the gas temperature reached $450^{\circ} \mathrm{C}$. The substrate used was steel sheet which was grit blasted prior to spray deposition.

The structure and morphology of the powder materials and coatings was studied by scanning electron microscopy (TESCAN Mira-3M). Hardness of coatings was measured by PMT-3 equipment. The amount of carbon was determined from the difference of mass change after oxidation at $700{ }^{\circ} \mathrm{C}$ for 30 minutes with catalyst coated aluminum powder before and after synthesis.

For one experiment, 35 grams of aluminum powder were filled up from the top and kept in an argon atmosphere of $400 \mathrm{~cm}^{3} / \mathrm{min}$ to replace oxygen and to heat the powder to the synthesis temperature for 10 min. After heating the reactor to $550^{\circ} \mathrm{C}$ hydrogen was added at a rate of $440 \mathrm{~cm}^{3} / \mathrm{min}$ for 20 minutes, to convert catalyst particles to Ni. Further acetylene was substituted for argon at a flow rate $53 \mathrm{~cm}^{3} / \mathrm{min}$. The Synthesis was also carried out for 20 minutes. Cooling to room temperature was carried out in argon at a flow rate $400 \mathrm{~cm}^{3} / \mathrm{min}$ outside of the furnace. Synthesis parameters are shown graphically in fig. $1, b$. 


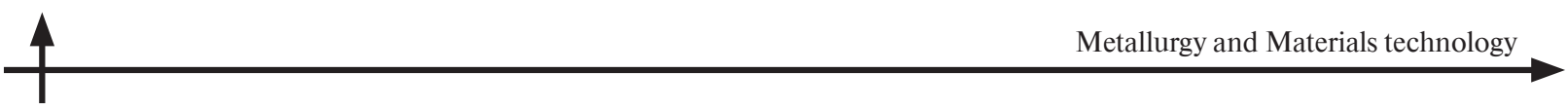

a)

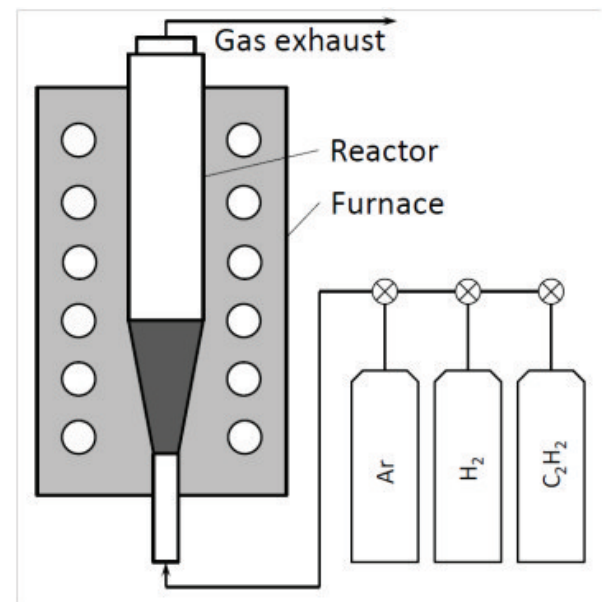

b)

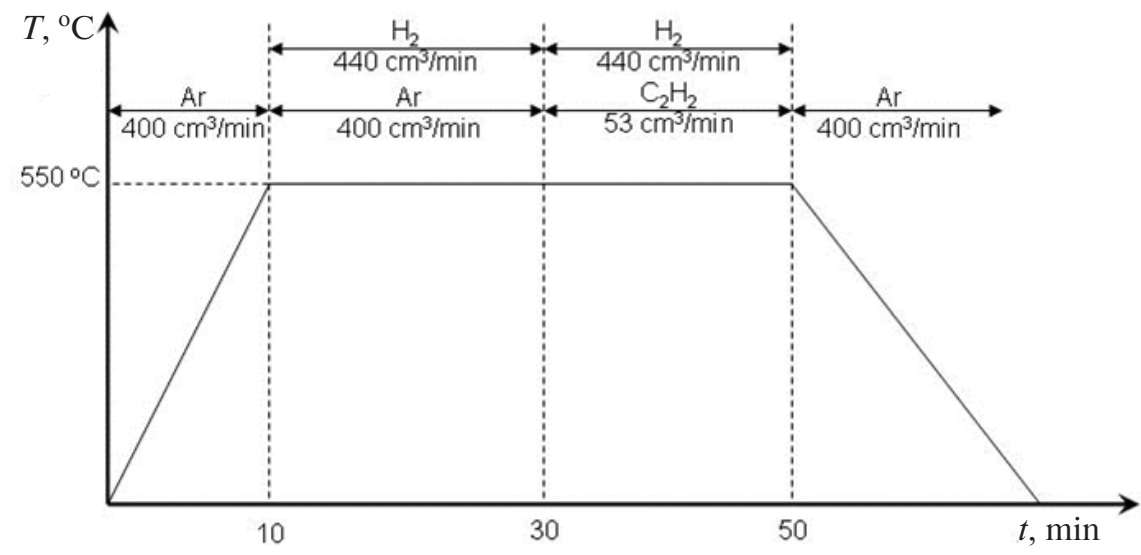

Fig. 1. Schematic of the experimental setup (a) and synthesis mode (b)

\section{Experimental results}

To grow carbon nanostructures, a nickel was preliminary deposited on the surface of the aluminum powder. Application of a nickel catalyst was conducted by vacuum-drying the powder in a water solution of nickel nitrate $\mathrm{Ni}\left(\mathrm{NO}_{3}\right)_{2} \cdot 6 \mathrm{H}_{2} \mathrm{O}$. Solution concentration varied from 10 to $80 \mathrm{~g} / 1$. After deposition on aluminum the salt-particle powder was subjected to a heat treatment step to remove residual moisture and convert salt decomposition oxide $(\mathrm{NiO})$. Annealing was performed under an argon atmosphere at temperatures of 100 and $250{ }^{\circ} \mathrm{C}$ for 30 minutes and at $400{ }^{\circ} \mathrm{C}$ for 60 minutes.

By varying the concentration of $\mathrm{Ni}$ catalyst were obtained composite materials containing from 0,63 to 2,2 wt. $\%$ carbon. The obtained powders were studied by scanning electron microscopy (fig. 2). From micro images seen that the carbon product has a tubular structure and cover the matrix particles virtually fully. Carbon structures have a diameter from 50 to $100 \mathrm{~nm}$ and a length more than 1 micron.

The resulting powders were applied onto a steel substrate by cold gas-dynamic spraying. The composite powders with 1 and 2 wt.\% CNFs were used to create coatings.

The resulting coating is plastically deformed aluminum particles stuck together (fig. 3, $a, c$ ) wherein the carbon nanostructures are evenly distributed over the coverage area. At high magnifications it can be seen carbon nanostructures are present in the sample, however, their number became significantly less and the length less than 1 micron. This may be due to the separation of longer nanofibers from the surface of aluminum particles during spraying. Reduction of fiber length could occur as well due to fiber fracture, which occurs upon impact of the particles with substrate. 
a)

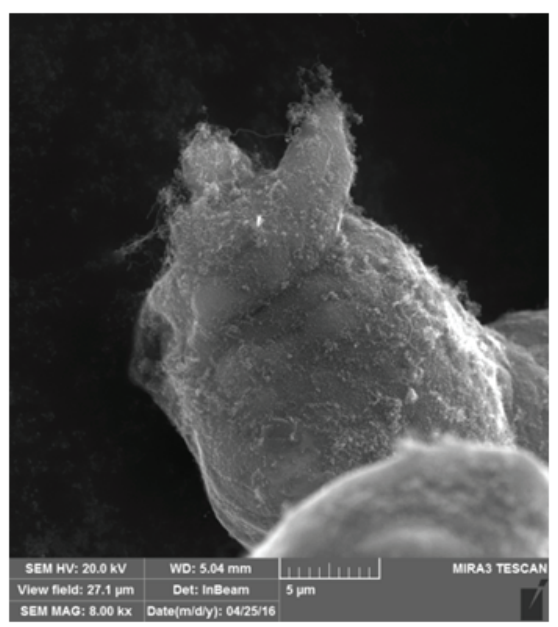

c)

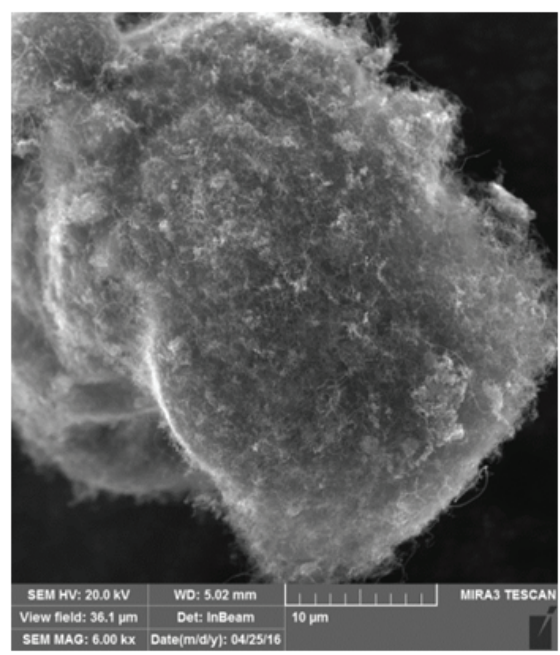

b)

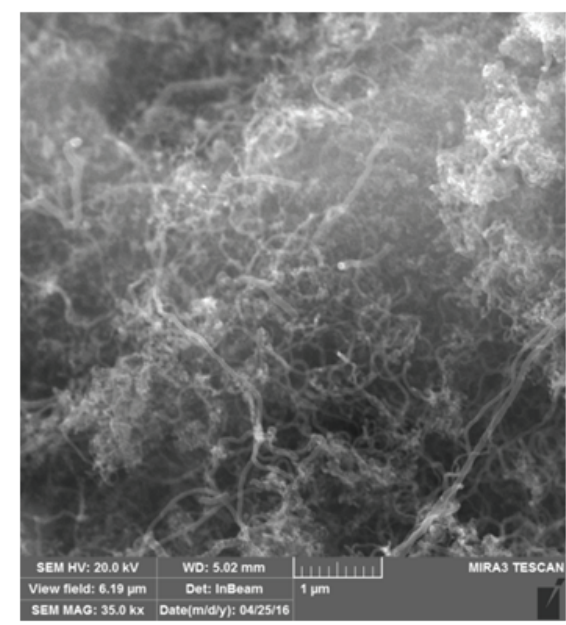

d)

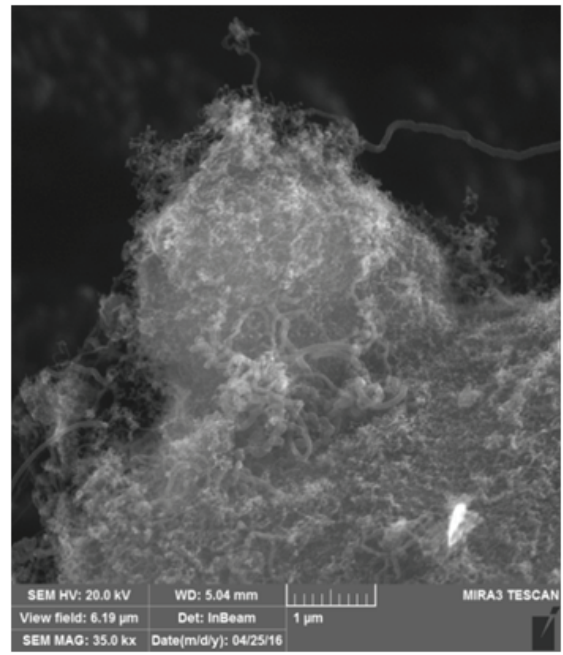

Fig. 2. SEM images of the powder composite material with carbon content of 1 wt. $\%(a, b)$ and 2 wt. $\%(c, d)$ 


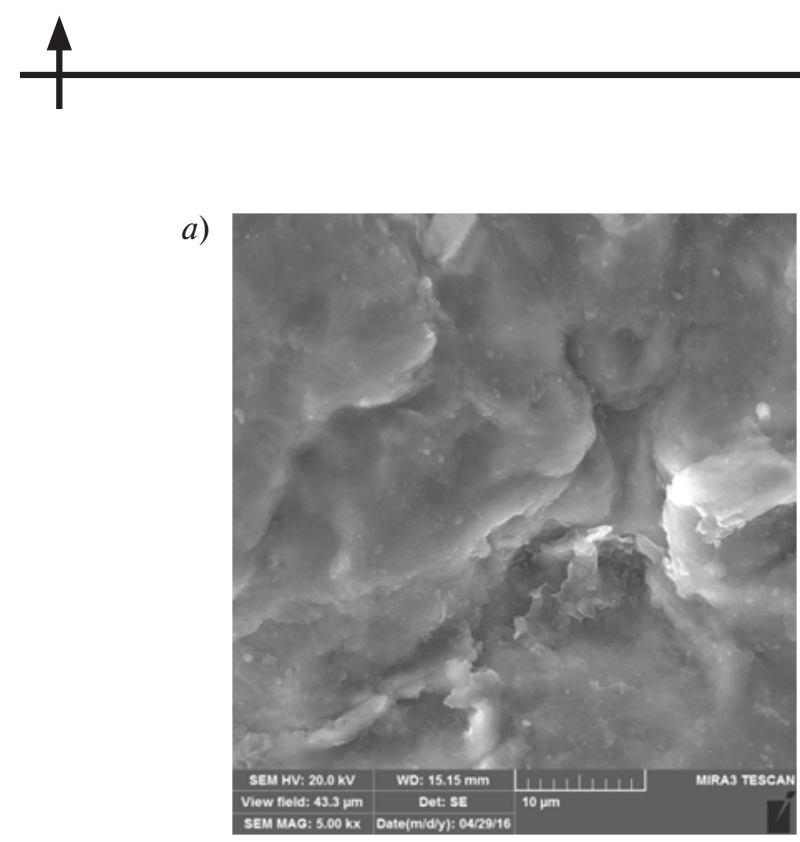

c)

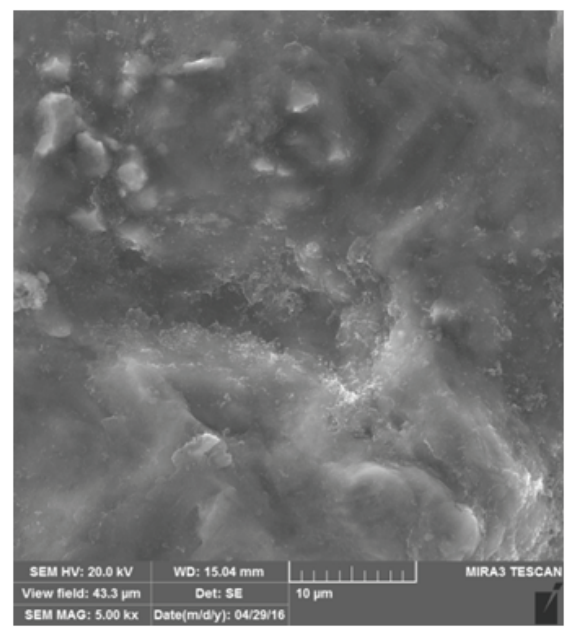

b)

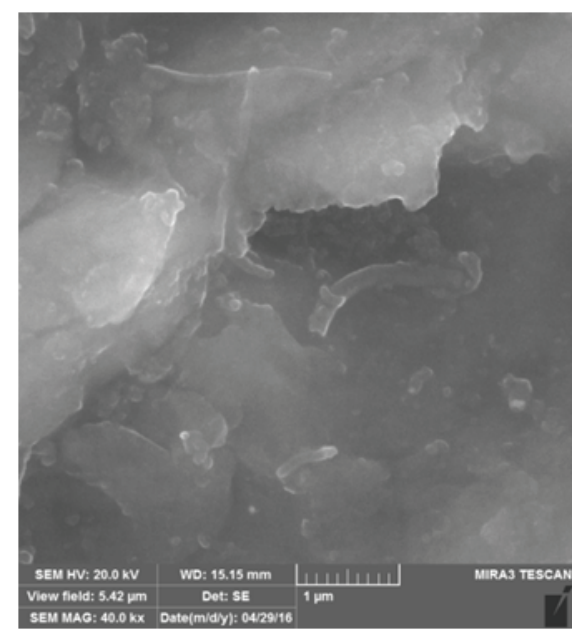

d)

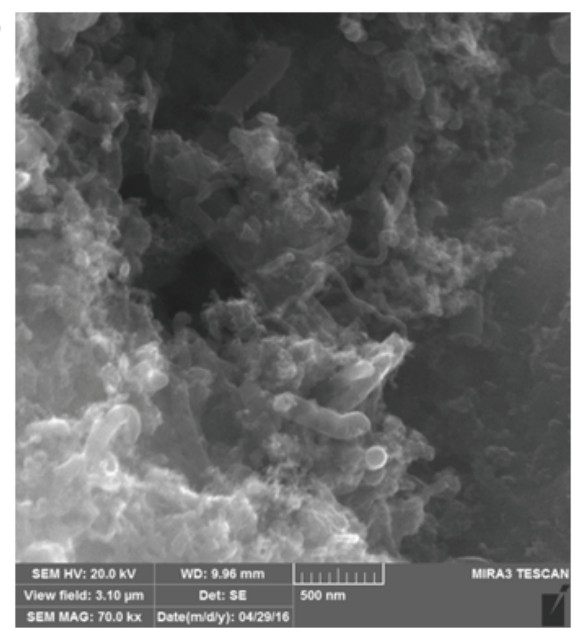

Fig. 3. SEM image surface coatings obtained by CS when the content in powders of 1 wt. $\%(a, b)$ and 2 wt. $\%(c, d)$ of carbon

Fig. 4 shows SEM images of the polished crosssection of $\mathrm{Al}-1 \mathrm{wt} . \% \mathrm{CNFs}$ and $\mathrm{Al}-2 \mathrm{wt} . \% \mathrm{CNFs}$ coatings. It can be seen that thin coatings of about 20 $\mu \mathrm{m}$ were formed by cold spraying. A coating with $1 \%$ CNFs has a more dense structure than a coating with $2 \%$ CNFs. Porosity between particles was a result of insufficient deformation of aluminum particles. The increasing of CNT content leads to deterioration of adhesion between the aluminum particles.
The Al-CNFs coatings demonstrated about $60 \%$ increase in the hardness compared with pure $\mathrm{Al}$ coatings. If the average Vickers microhardness for $\mathrm{Al}$ coating is $32 \mathrm{HV}$ then the $\mathrm{Al}-1 \mathrm{wt} . \% \mathrm{CNFs}$ and $\mathrm{Al}-2$ wt \% CNFs coating amounts to $51 \mathrm{HV}$ and 53 $\mathrm{HV}$ respectively. The hardness of the samples which contained $2 \% \mathrm{CNF}$ has no significant changes compared to $1 \%$ of the CNF - it is a result of increased porosity. 
a)
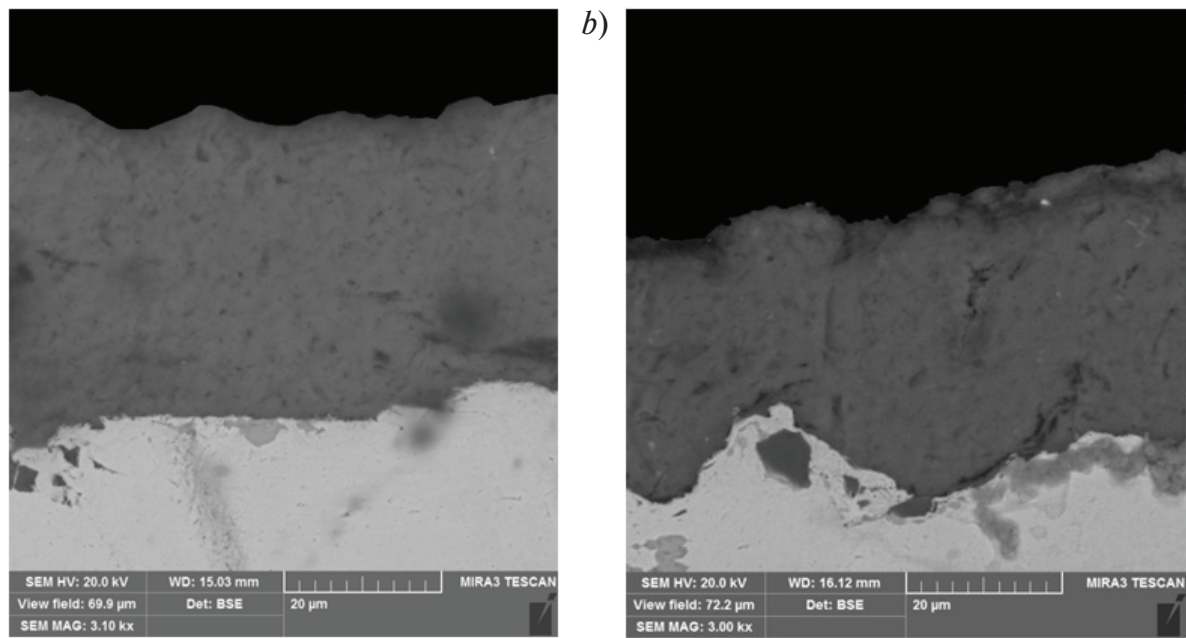

Fig. 4. SEM images of the polished cross-section of Al-1 wt.\% CNFs $(a)$ and $2 \mathrm{wt} \%$ CNFs $(b)$ coatings

\section{Conclusions}

Composite Al-based powder with carbon nanofibers uniformly distributed over the surface had been successfully synthesized by CVD process in a fluidized bed reactor. Content of CNF on the powder surface can be varied by variation of $\mathrm{Ni}$ catalyst content from 0,5 up to 2 mass. $\%$. The provided apparatus for synthesis allow to obtain tens grams of powdered material per hour, as well of its advantages of uniform processing of carbon nanostruc- tures across the surface of the powder, as well as the process scalability. The obtained composite powder has the possibility to be used in cold spray process to create coatings. It was determined that the carbon fibers are present and evenly distributed in the coatings. The Al-CNFs coatings showed about $60 \%$ increase in the hardness compared with pure $\mathrm{Al}$ coatings.

This study was supported by Russian Foundation for Basic Research (project no. 16-32-80092)

\section{REFERENCES}

1. Bakshi [et al]. Carbon Nanotube Reinforced Metal Matrix Composites. International Materials Reviews. 2010. Vol. 55 (1). P. 41-64.

2. Min-Feng Yu, Laurie O., Dyer M.J., Moloni K., Kelly T.F., Ruoff R.S. Strength and breaking mechanism of multiwalled carbon nanotubes under tensile load. Science. 2000. Vol. 287. P. 637-640.

3. Kim P., Shi L., Majumdar A., McEuen P.L. Thermal Transport Measurements of Individual Multiwalled Nanotubes. Phys. Rev. Lett. 2001. Vol. 87 (21). P. $215502-$ $1-215502-4$.

4. Chen W.X., Tu J.P., Wang L.Y., Gan H.Y., Xu Z.D., Zhang X.B. Tribological application of carbon nanotubes in a metal-based composite coating and composites. Carbon. 2003. Vol. 41. P. 215-222.

5. Tu J.P., Yang Y.Z., Wang L.Y., Ma X.C., Zhang X.B. Tribological properties of carbon-nanotube-reinforced copper composites. Tribol. Lett. 2001. Vol. 10. P. 225228.

6. He C., Zhao N., Shi C., Du X., Li J., Li H., Cui Q. An Approach to Obtaining Homogeneously Dispersed Carbon Nanotubes in Al Powders for Preparing Reinforced Al-Matrix Composites. Adv.Mater. 2007. Vol. 19. P. 1128-1132.
7. Tokunaga T., Kaneko K., Horita Z. Production of aluminum-matrix carbon nanotube composite using high pressure torsion. Mater. Sci. Eng. A. 2008. Vol. 490. P. 300-304.

8. Bakshi S.R., Singh V., Balani K., McCartney D.G., Seal S., Agarwal A. Carbon nanotube reinforced aluminum composite coating via cold spraying. Surface \& Coatings Technology. 2008, Vol. 202. P. 5162-5169.

9. Carreno-Morelli E., Yang J., Couteau E., Hernadi K., Seo J.W., Bonjour C., Forro L., Schaller R. Carbon nanotube/magnesium composites. Phys. Status Solidi (a). 2004. Vol. 201 (8). R53-R55.

10. Feng Y., Yuan H.L., Zhang M. Fabrication and Properties of Silver-Matrix Composites Reinforced by Carbon Nanotubes. Mater. Charact. 2005. Vol. 55. P. 211-218.

11. Arai S., Endo M., Kaneko N. Ni-deposited Multiwalled Carbon Nanotubes by Electrodeposition. Carbon. 2004. Vol. 42. P. 641-644.

12. Kim K.T., Cha S.I., Hong S.H., Hong S.H. Microstructures and tensile behavior of carbon nanotube reinforced Cu matrix nanocomposites. Mater. Sci. Eng., A. 2006. Vol. 430. P. 27-33. 
13. Pang L.-X., Sun K-N., Ren S., Sun C., Fan R-H., Lu Z-H. Fabrication and microstructure of Fe3Al matrix composite reinforced by carbon nanotube. Mater. Sci. Eng., A. 2007. Vol. 447. P. 146-149.

14. Esawi A.M.K., El Borady M.A. Carbon nanotubereinforced aluminium strips. Comput. Sci. Tech. 2008. Vol. 68 (2). P. 486-492.

15. Laha T., Agarwal A., McKechnie T., Seal S. Synthesis and characterization of plasma spray formed carbon nanotube reinforced aluminum composite. Mater. Sci. Eng., A. 2004. Vol. 381. P. 249-258.
16. Laha T., Agarwal A. Effect of sintering on thermally sprayed carbon nanotube reinforced aluminum nanocomposite. Mater. Sci. Eng., A. 2008. Vol. 480. P. 323-332.

17. Moridi A., Hassani-Gangaraj S. M., Guagliano M., Dao M. Cold spray coating: review of material systems and future perspectives. Surface Engineering. 2014. Vol. 36 (6). P. 369-395.

18. Zhang D., Shipway P.H., McCartney D.G. Cold gas dynamic spraying of aluminum: The role of substrate characteristics in deposit formation. J. Therm. Spray Technol. 2005. Vol. 14. P. 109-116.

\section{СПИСОК ЛИТЕРАТУРЫ}

1. Bakshi [et al]. Carbon Nanotube Reinforced Metal Matrix Composites // International Materials Reviews. 2010, Vol. 55 (1). P. 41-64.

2. Min-Feng Yu, Laurie O., Dyer M.J., Moloni K., Kelly T.F., Ruoff R.S. Strength and breaking mechanism of multiwalled carbon nanotubes under tensile load // Science. 2000. Vol. 287. P. 637-640.

3. Kim P., Shi L., Majumdar A., McEuen P.L. Thermal Transport Measurements of Individual Multiwalled Nanotubes // Phys. Rev. Lett. 2001. Vol. 87 (21) P. 215502-1-215502-4.

4. Chen W.X., Tu J.P., Wang L.Y., Gan H.Y., Xu Z.D., Zhang X.B. Tribological application of carbon nanotubes in a metal-based composite coating and composites // Carbon. 2003. Vol. 41. P. 215-222.

5. Tu J.P., Yang Y.Z., Wang L.Y., Ma X.C., Zhang X.B. Tribological properties of carbon-nanotube-reinforced copper composites // Tribol. Lett. 2001. Vol. 10. P. 225228.

6. He C., Zhao N., Shi C., Du X., Li J., Li H., Cui Q. An Approach to Obtaining Homogeneously Dispersed Carbon Nanotubes in Al Powders for Preparing Reinforced Al-Matrix Composites // Adv.Mater. 2007. Vol. 19. P. 1128-1132.

7. Tokunaga T., Kaneko K., Horita Z. Production of aluminum-matrix carbon nanotube composite using high pressure torsion // Mater. Sci. Eng. A. 2008. Vol. 490. P. 300-304.

8. Bakshi S.R., Singh V., Balani K. , McCartney D.G., Seal S., Agarwal A. Carbon nanotube reinforced aluminum composite coating via cold spraying // Surface \& Coatings Technology. 2008. Vol. 202. P. 5162-5169.

9. Carreno-Morelli E., Yang J., Couteau E., Hernadi K., Seo J.W., Bonjour C., Forro L., Schaller R. Carbon nanotube/magnesium composites // Phys. Status Solidi (a). 2004. Vol. 201 (8). R53-R55.

10. Feng Y., Yuan H.L., Zhang M. Fabrication and Properties of Silver-Matrix Composites Reinforced by Carbon Nanotubes // Mater. Charact. 2005. Vol. 55. P. 211-218.

11. Arai S., Endo M., Kaneko N. Ni-deposited Multiwalled Carbon Nanotubes by Electrodeposition // Carbon. 2004. Vol. 42. P. 641-644.

12. Kim K.T., Cha S.I., Hong S.H., Hong S.H. Microstructures and tensile behavior of carbon nanotube reinforced $\mathrm{Cu}$ matrix nanocomposites. // Mater. Sci. Eng., A. 2006. Vol. 430. P. 27-33.

13. Pang L.-X., Sun K-N., Ren S., Sun C., Fan R-H., Lu Z-H. Fabrication and microstructure of Fe3Al matrix composite reinforced by carbon nanotube // Mater. Sci. Eng., A. 2007. Vol. 447. P. 146-149.

14. Esawi A.M.K., El Borady M.A. Carbon nanotubereinforced aluminium strips // Comput. Sci. Tech. 2008. Vol. 68 (2). P. 486-492.

15. Laha T., Agarwal A., McKechnie T., Seal S. Synthesis and characterization of plasma spray formed carbon nanotube reinforced aluminum composite // Mater. Sci. Eng., A. 2004. Vol. 381. P. 249-258.

16. Laha T., Agarwal A. Effect of sintering on thermally sprayed carbon nanotube reinforced aluminum nanocomposite // Mater. Sci. Eng., A. 2008. Vol. 480. P. 323-332.

17. Moridi A., Hassani-Gangaraj S. M., Guagliano M., Dao M. Cold spray coating: review of material systems and future perspectives // Surface Engineering. 2014. Vol. 36 (6). P. 369-395.

18. Zhang D., Shipway P.H., McCartney D.G. Cold gas dynamic spraying of aluminum: The role of substrate characteristics in deposit formation // J. Therm. Spray Technol. 2005. Vol. 14. P. 109-116. 


\section{СВЕДЕНИЯ ОБ АВТОРAX/AUTHORS}

TONITZKI Andreas - Peter the Great St. Petersburg Polytechnic University.

29 Politechnicheskaya St., St. Petersburg, 195251, Russia.

E-mail: a.tonitzki@gmx.de

ТОНИИТЗКИ Андреас - студент Санкт-Петербургского политехнического университета

Петра Великого.

195251, Россия, г. Санкт-Петербург, Политехническая ул., 29.

E-mail: a.tonitzki@gmx.de

SKVORTSOVA Aleksandra N. - Peter the Great St. Petersburg Polytechnic University.

29 Politechnicheskaya St., St. Petersburg, 195251, Russia.

E-mail: hlobystic@mail.ru

СКВОРЦОВА Александра Николаевна - аспирант Санкт-Петербургского политехнического университета Петра Великого.

195251, Россия, г. Санкт-Петербург, Политехническая ул., 29.

E-mail: hlobystic@mail.ru

KOLTSOVA TatiianaS. - Peter the Great St. Petersburg Polytechnic University.

29 Politechnicheskaya St., St. Petersburg, 195251, Russia.

E-mail: annelet@yandex.ru

КОЛЬЦОВА Татьяна Сергеевна - кандидат технических наук инженер Санкт-Петербургского политехнического университета Петра Великого.

195251, Россия, г. Санкт-Петербург, Политехническая ул., 29.

E-mail: annelet@yandex.ru

GANIN Sergei V. - Peter the Great St. Petersburg Polytechnic University.

29 Politechnicheskaya St., St. Petersburg, 195251, Russia.

E-mail: s.v.ganin@gmail.com

ГАНИН Сергей Владимирович - кандидат технических наук доцент Санкт-Петербургского политехнического университета Петра Великого.

195251, Россия, г. Санкт-Петербург, Политехническая ул., 29.

E-mail: s.v.ganin@gmail.com

DANILOVA Marina A. - Peter the Great St. Petersburg Polytechnic University.

29 Politechnicheskaya St., St. Petersburg, 195251, Russia.

E-mail: marina.rakovskay@yandex.ru

ДАНИЛОВА Марина Андреевна - аспирант Санкт-Петербургского политехнического университета Петра Великого.

195251, Россия, г. Санкт-Петербург, Политехническая ул., 29.

E-mail: marina.rakovskay@yandex.ru

SHAMSHURIN Aleksei I. - Peter the Great St. Petersburg Polytechnic University.

29 Politechnicheskaya St., St. Petersburg, 195251, Russia.

E-mail: sham_a@mail.ru

ШАМШУРИН Алексей Игоревич - научный сотрудник Санкт-Петербургского политехнического университета Петра Великого.

195251, Россия, г. Санкт-Петербург, Политехническая ул., 29.

E-mail: sham_a@mail.ru 